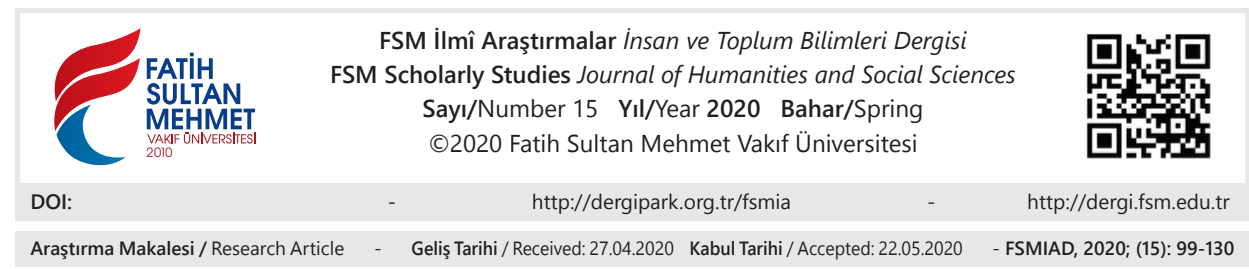

\title{
Fatih Külliyesi ve Ayasofya-i Kebir Vakfı (Hayır Müesseseleri, Hizmetleri, Görevlileri ve Yönetimi) \\ Eyüp Sabri Kala*
}

\section{$\ddot{O} z$}

Fetihle birlikte Fatih İstanbul'u hızla yeniden yapılandırmaya başlamıştır. İstanbul nahiyeler ve bunların altında mahalleler şeklinde idari birimlere ayrılmıştır. Bu nahiye ve mahallelerin hemen tamamı vakıflar tarafından kurulan vakıf eserler etrafında şekillenmiştir. Bu durum, Fatih'in İstanbul'un yeniden yapılanmasını vakıflar üzerinden planladığının göstergesidir.

Fatih kendi kurduğu Fatih Külliyesi ve Ayasofya-i Kebir Vakfi'yla Fatih, Ayasofya ve Vefa nahiyelerinin bizatihi kurucusu olmuş, vakfin hayır müesseseleri bu nahiyelerin merkezini teşkil etmiştir. Sur dışında Eyüp Sultan Vakfi'yla da Eyüp Sultan semtinin kurucusu olmuştur. Fatih beylerine, paşalarına emir ve izin vererek her birinin İstanbul'un bir yerini belirleyip orada kendi adlarıyla vakıflarını ve mahallelerini kurmalarını teşvik etmiştir. Kurulan vakıf müesseseleri nahiye ve mahallelerin her tür sosyal hizmetlerini görecek şekilde planlanmıştır. Bu faaliyetler neticesinde ve kurulan vakıf müesseseleri sayesinde İstanbul ilim, irfan, kültür, sanat, inanç, sağlık, sosyal dayanışma ve yardımlaşma ve şehircilik alanlarında İslam medeniyetinin en önemli şehirlerinden biri haline gelmiştir.

* Dr. Öğr. Üyesi, Fatih Sultan Mehmet Vakıf Üniversitesi Hukuk Fakültesi, İstanbul/Türkiye, ekala@hotmail.com, orcid.org/ 0000-0001-6058-7905 
Çalışmamızda, Fatih Sultan Mehmed'in kurduğu Fatih Külliyesi ve Ayasofya-i Kebir Vakfı'na ait Türk ve İslam Eserleri Müzesi’nde 2202 numarayla kayıtlı vakfiye esas alınarak vakfın kurmuş olduğu hayır müesseseleri, bu müesseselerin görevlileri, ücretleri, yapacakları hizmetler, vakfın idamesini sağlayacak akarlar ve vakfın yönetimi ele alınmakta, vakfın yapmış olduğu bu hizmetlerin sosyal politika açısından değerlendirmesi yapilmaktadir.

Anahtar Kelimeler: Sosyal politika, vakıf, sosyal hizmetler, Fatih Külliyesi ve Ayasofya-i Kebir Vakfi.

\section{The Fatih Complex and Hagia Sophia Foundation (Charities, Social Works, Officials and Management)}

\section{Abstract}

Fatih began to quickly restructure Istanbul with the conquest. Istanbul is divided into administrative units in the form of sub-districts and neighborhoods below them. Almost all of these districts and neighborhoods are shaped around foundation's established. This indication shows us that Fatih planned the reconstruction of Istanbul through foundations.

Fatih Social Complex and Hagia Sophia Foundation were established by Fatih, and Fatih became the founder of the Fatih, Hagia Sophia and Vefa sub-districts, and the charities of the foundation constituted the center of these sub-districts. He also became the founder of the Eyup Sultan district with the Eyub Sultan Foundation. He encouraged his lords and generals to establish their foundations, and allow each of them to determine the location. In those foundations were planned to see all kinds of social services of townships and neighborhoods. As a result of these activities and the foundation institutions, Istanbul has become one of the most important cities in Islamic civilization in terms of science, knowledge, culture, art, belief, health, social solidarity and urbanism.

In this study it is based on the Fatih Social Complex and Hagia Sophia Foundation which established by Fatih. Organization of the foundation, and charitable institutions which established by the foundation, and their workers, the wages of workers, services of the institutions, income of the foundation, and management of the foundation are examined. In addition these, the serves of the foundation are reviewed in terms of social policy.

Keywords: Social policy, foundation, social work, Fatih Social Complex and Hagia Sophia Foundation. 


\section{Giriş}

Fatih'in Konstantinapolis'i İstanbul'a dönüştürme hamlesinin önemli bir parçası olarak kendisinin kurduğu vakıflar, aynı zamanda vakıflar üzerinden medeniyet inşasının somut örneklerinden birini teşkil etmektedir. Fatih'in İstanbul'da kurduğu iki vakıf bulunmaktadır. Birincisi, Eyüp Sultan Hazretleri'nin türbesinin çevresinde kurduğu Eyüp Vakfı, ikincisi ise Fatih Külliyesi ve Ayasofya-i Kebir Vakfı'dır. Eyüp Sultan Vakfı tarafından kurulan Eyüp Külliyesi, Eyüp Sultan Camii, medresesi ve imaretinden oluşmaktadır. Medrese ve imaret kısmı günümüze ulaşmamakla birlikte, Eyüp Sultan Camii halen Eyüp Sultan ilçesinin merkezini oluşturmaktadır. Böylelikle Fatih, sur dışındaki idari birimler olan Bilâd-1 Selâse'den (Eyüp, Galata ve Üsküdar) Eyüp'ün vakıf yoluyla kurucusu olmuştur. Fatih Külliyesi ve Ayasofya-i Kebir Vakfı ise sur içinde Fatih, Ayasofya ve Vefa nahiyelerinin kurucu gücü olmuştur. Fatih semti ile Ayasofya ve Vefa külliyelerinin çevresi İstanbul'un inanç, ilim, irfan, kültür, sağlık, yönetim ve ticaret merkezi haline gelmiş, sosyal hayatın kalbi buralarda atmaya başlamıştır. Fatih'in izlemiş olduğu sosyal politika, fetihten sonra İstanbul'daki yeni yerleşim ve yaşam modelini şekillendirmiş, şehrin ilim, kültür, inanç ve sosyal hayatına mühür vurmuş, sonuç olarak da İstanbul İslam Medeniyeti'nin en önemli şehirlerinden biri haline gelmiştir. Fatih'ten sonra bu politika II. Bayezid, Yavuz Sultan Selim ve Kanuni Sultan Süleyman tarafindan da devam ettirilerek zirveye ulaştırılmıştır.

Çalışmamızda, Fatih Sultan Mehmed'in "Fatih Külliyesi ve Ayasofya-i Kebir Vakfi" ele alınmaktadır. Vakıfla ilgili muhtelif vakfiyeler bulunmakla birlikte bu çalışmada, aslı Türk ve İslam Eserleri Müzesi’nde 2202 (eski 666) numarada kayıtlı vakfiye esas alınmıştır. Vakfiyenin Vakıflar Genel Müdürlüğü tarafından yaptırılan çevirisi ile Ahmet Beyatlı tarafindan Fâtih Sultan Mehmed'in 877/1472 Tarihli Vakfiyesi adlı kitapta yayınlanan çevirisinden yararlanılmıştır. Yine aynı vakfiyeyle ilgili Osman Ergin tarafından yayımlanan Fatih Imareti Vakfiyesi kitabında yer alan değerlendirmelerden istifade edilmiştir. Vakfiyeye yapılan atıflarda, Ahmet Beyatlı tarafından yayımlanan kitaptaki Arapça yazımda yer alan satır numaraları esas alınmış ve kısaca "sr" olarak ifade edilmiştir.

Vakfiyedeki bilgiler belli bir tasniflemeye tabi tutularak vakfın hayır müesseseleri, bu müesseselerde görevli personel, personel ücretleri, istihdam şartlar1, vakfin yönetimi ve yöneticileri, vakfın idamesini sağlamak üzere vakfedilen akarlar ele alınmış, sonuç itibariyle vakfın sosyal politika alanında yaptığı hizmetler değerlendirilmiştir. 


\section{Vakfiyenin Genel Özellikleri ve Tescil Süreci}

\section{Vakfiyenin Genel Özellikleri}

Çalışmamızın dayandığı vakfiye, Türk ve İslam Eserleri Müzesi’nde 2202 (eski 666) numarayla kayıtlı bulunmaktadır. Bu vakfiyenin Evkaf Nezareti döneminde yapılan suret kaydı ise Vakıflar Genel Müdürlüğü Arşivi’nde İstanbul 6. Vakfiye defterinde 46 numarada kayıtlıdır. Aynı vakfiyenin Cumhuriyet döneminde yapılan Latin harfli çevirisi de Vakıflar Genel Müdürlüğü Arşivi'nde 575 numaralı defterde 82. sayfadan itibaren 46 sira numarası ile kayıtlıdır.

Vakfiye tomar halinde olup $33 \mathrm{~cm}$. x 38,5 mt. ebadındadır. Yeşil atlas kumaş üzerine yapıştırılmıştır. Arapça olarak kaleme alınmış olup, baş kısmı eksiktir. Orta kısmında ise çürümeler vardır.

Vakfiye, Osman Ergin ${ }^{1}$ tarafından otuz beş sayfalık bir değerlendirmeyle birlikte tıpkıbasım olarak; Ahmet Beyat $11^{2}$ tarafından değerlendirme, tıpkıbasım, Arap harfleriyle Arapça yazım ve Türkçe çevirisiyle birlikte yayımlanmıştır. Ayrıca, yayımlanmamakla birlikte vakfiyenin Vakıflar Genel Müdürlüğü’nce yapılan ve 575 numaralı defterin 82. sayfasından itibaren 46 numarayla kayıtlı Latin harfli Türkçe çevirisi bulunmaktadır. ${ }^{3}$

Ergin, vakfiyenin tıpkıbasımını yaparken tomar halinde ve yeşil atlasa yapışık olan vakfiyeyi 68 sayfa halinde yayımlamıştır. Vakfiyenin baş tarafı edebi bir parça şeklinde Fatih'in methiyesinden oluşmaktadır. Ergin'in tasnifine göre 3-52. sayfalarda vakfin mukataaya bağlanan binaları ve arsaları, 52-55. sayfalar arasında İstanbul dışında vakfedilen araziler, 51-61 arasında İstanbul'daki ve Üs-

1 Osman Ergin, Fatih İmareti Vakfiyesi, İstanbul, İstanbul Belediyesi Yayınları, 1945.

2 Ahmet Beyatl1, Fâtih Sultan Mehmed'in 877/1472 Tarihli Vakfiyyesi, Türk Tarih Kurumu Yayınlar1, 2013.

3 Fatih Külliyesi veAyasofya-i Kebir vakfına ait olup yayımlanan diğer vakfiye nüshaları için bkz.

Topkapı Sarayı Müzesi Arşivi’nde 1808 numarada kayıtlı 1472/1473 tarihli tomar halindeki vakfiye ile yine aynı arşivde 7744-4 numarada kayıtlı 19 Temmuz 1496 istinsah tarihli Arapça vakfiye nüshaları: Tahsin Öz, Zwei Suftuftungsurkunden des Sultans Mehmed II. Fatih, İstanbul, Alman Arkeoloji Enstitüsü Yayınları, 1935; Tapu Kadastro Genel Müdürlüğü Arşivi'nde yeni 2291, sıra 2302'de kayıtlı vakfiye nüshas1: TKGM İnternet sitesi ve Prof. Dr. Ahmet Akgündüz - Prof. Dr. Sait Öztürk - Yaşar Baş, Üç Devirde Bir Mabed: Ayasofya, İstanbul, OSAV Yayınları, 2005; Vakıflar Genel Müdürlüğü Arşivi’nde 1373-46 numarada kayıtlı Türkçe vakfiye nüshası: Vakıflar Genel Müdürlüğü, Fatih Mehmet II Vakfiyeleri, Ankara, Vakıflar Genel Müdürlüğü Yayınları, 1938 ve Vakıflar Genel Müdürlüğü - Çamlıca Kültür ve Yardım Vakfı, Fatih Sultan Mehmed Vakfiyeleri, İstanbul, Vakıflar Genel Müdürlügü ve Çamlıca Kültür ve Yardım Vakfı Yayınları, 2003. 
küdar'daki akarlar, 65. sayfaya kadar tekrar şehir dışındaki akarlar sayılmaktadır. 65. sayfadan itibaren vakfın yönetimi, görevlileri, ücretler, vakıf gelirlerinin sarf yerleri ve diğer vakıf şartları düzenlenmektedir. Son sayfada da vakfın Evkaf Nezareti'nce İstanbul 6 numaralı Vakfiye Defteri'ne tescil edilmesiyle ilgili bilgiler yer almaktadır. ${ }^{4}$ Ahmet Beyatlı tarafindan yapılan yayında ise vakfiye tıpkıbasımı yüz sayfa halinde yayımlanmıştır.

Vakfiye üzerinde yaptığımız incelemede, metnin akışı itibariyle aşağıdaki hususlar tespit edilmiştir.

- Baş kısımdaki kopukluk vakfiyenin giriş ve dua faslının bir bölümünü kapsamaktadır. Halihazır elimizde bulunan vakfiyenin ilk satırından itibaren satır numarası verildiğinde, vakfiyenin giriş ve dua kısmı 1-18. satırlar arasında bulunmaktadır. Bu vakfiyedeki giriş ve dua kısmı, diğer Fatih Külliyesi ve Ayasofya vakfiye nüshalarına göre daha kısadır.

- 19-35. satırlar arasında, vakfin hayır müesseseleri belirlenmektedir. Buna göre vakfın hayır müesseseleri, Fatih Camii, Sekiz Medrese (Sahn-1 Seman Medreseleri), Ayasofya Camii, Galata Camii (günümüzde Karaköy'deki Arap Camii) ve Debbağlar Mahallesi'ndeki Mâristan'dır (eski bimarhâne, darüşşifa). Hayratın sayıldığı bu kısımda yer almamakla birlikte, vakıf görevlilerinin ve ücretlerinin belirlendiği son kısımda Silivri Kalesi Camii'nin görevlileri ve cami tahsisatları da belirlenmekte ve böylece hayrat arasına alınmaktadır. Yine son kısımda Mâristan görevlileri ve tahsisatları belirlenirken, bu tesise bağlı olarak faaliyet gösteren Tabhane, görevlileri, ücretleri ve tahsisatları belirlenmektedir.

- 36-889. satırlarda vakfin akarları sayılmaktadır.

- 890-899. satırlarda, mütevelli ve vakıf nazırıyla ilgili düzenlemeler; 899906. satırlarda Sahn-1 Seman Medreseleri görevlileri, ücretleri, medrese ve talebe tahsisatlar1; 906-924. satırlarda Fatih Camii görevlileri, ücretleri ve cami tahsisatları ile vakıf nazırının ücreti; 925-936. satırlarda, Ayasofya Camii görevlileri, ücretleri ve cami tahsisatlar1; 936-939. satırlarda Galata Camii görevlileri, ücretleri ve cami tahsisatları; 939-940. satırlarda, Silivri Camii görevlileri, ücretleri ve cami tahsisatları; 941-956. satırlarda Debbağlar Mahallesi'ndeki Darüşşifa'nın (Mâristan'ın) ve tabhanesinin (aşhane) görevlileri, ücretleri ve hizmet şartları belirlenmektedir.

- 956-962. satırlarda, mütevellinin görevleri ve çalışan personelin genel istihdam şartları düzenlenmekte, 963. satırdan itibaren vakfiyenin tesciliyle 
ilgili kadı huzurundaki usuli işlemler anlatılmaktadır. Fatih'in vakfettiği malları Sadrazam Mahmud Paşa'ya teslim ettiğine dair beyanı, bilahare usulen vakıftan rücuu, Mahmud Paşa'nın sırf vakf ettim sözü ile vakfın lâzım vakıf olacağına dair müçtehid imamların görüşlerine göre vakfın tescilini talep etmesi ve hâkimin vakfın sıhhat ve lüzumuna karar verdiğine dair hükmü yer almaktadır.

- Son kısımda, vakıf şartlarını değiştiren, vakfi bozmak veya iptal etmek isteyenlerle ilgili vakıf bedduası yer almaktadır. Vakfiye nihayetinde, Evkaf Nezareti'nin, Vakfiyenin İstanbul 6. Vakfiye defterine 46 sira numarasıyla kaydına ilişkin şerhi yer almaktadır.

\section{Tescil Süreci}

\section{a. Tescil Davasina Katılanlar}

Vakfiye metninden, vakfın tescili için Fatih Sultan Mehmed'in vakfeden s1fatıyla mahkemeye bizzat katıldığı anlaşılmaktadır. Vakıf adına vakfedilenleri teslim alan (tescil için tayin olunan mütevelli) ve vakıf adına vakfın sahih ve lâzım vakıf olduğuna karar verilmesini talep eden ise Sadrazam Mahmud Paşa'dır. Vakfiyenin sıhhat ve lüzumuna ilişkin kararın yer aldığı satırda hâkimin ismi yer almamakta, "yukarıda ismi bulunan hâkim" ifadesiyle vakfiyenin baş kısmına atıf yapılmaktadır. Ancak vakfiyenin baş kısmı zamanla tahrip olup kopmuş olduğundan, vakfı tescil eden hâkimin isminin burada yer alıp almadığ 1 bilinememektedir. Vakfiyede Fatih'e ait tuğra bulunmamaktadır. Hâkim isminde olduğu gibi, vakfiyenin baş kısmı yıpranmadan önceki orijinal halinde Fatih'in tuğrasının yer alıp almadığg da bilinememektedir.

“... bundan sonra adı geçen Sultan, sözü edilen evkafin belirtilen tafsilatı ile tescilini isteyip Veziri bulunan ... Mahmud Paşa'ya teslim etti. ... yukarıda imzası bulunan hâkim, (vakfin) sihhat ve lüzumuna hükm ve tescil-i şer'î ile tescil etti". ${ }^{5}$

Vakfiyelerde genellikle hâkimin sihhat, lüzum ve tescil kararından hemen sonra kararın tarihi yer alır. İncelediğimiz vakfiyede bu kısımda herhangi bir tarih yer almadığı gibi, başka bir yerinde de tarih bulunmamaktadır. Baş tarafta kopan kısımda tarih olup olmadığ 1 ise bilinememektedir. Bununla birlikte, vakfiye içerisinde geçen yer ve şahıs isimlerinden, bu vakfiyenin tanzim tarihinin 1472-1473 olduğu anlaşılabilmektedir. 


\section{b. Vakfedilen Malların Teslimi, Vakıftan Rücu ve Vakfin Sihhat ve Lüzumuna İlişkin Karar}

Vakfiyede, Fatih Sultan Mehmed'in, vakfettiği malları vakfın tescili için mütevelli olarak belirlenen Veziriazam Mahmud Paşa'ya teslim ettiği belirtilmektedir.

“... bundan sonra müşarünileyh Sultan, mezkûr evkâfin mezbur tafsilatı ile tescilini murad edip veziri bulunan sâhib-i a'zam ve düstûr-ı hatîr-i muazzam, bedr-i tâmm-ı enver, şems-i mev'id-i ezher Mahmud Paşa 'ya teslim etti’"

$\mathrm{Bu}$ teslimden sonra, usuli işlem olarak Fatih yalnız vakfettim demekle vakfın lâzım bir vakıf olmadığını ifade ederek, vakfettiği malları geri istemiş, vakıf adına malları teslim alan Mahmud Paşa da müctehid imamların görüşüne göre "vakfettim" demekle vakıf artık lâzım (geri dönülemez) vakıf olmuştur diyerek malların geri verilmesi talebine itiraz etmiştir. Böylece hâkim huzurunda hukuki bir ihtilaf ve dava oluşmuştur. Hâkim vakfın artık sahih ve lâzım vakıf olduğuna ve tesciline karar vermiştir. Bu kararla birlikte vakıf hukuken bağlayıcı, geri dönülemez olarak mahkeme kararıla tescil edilmiştir.

“... ve bundan sonra, yalnız vakfettim demekle vakfin ademi lüzumunu iddia ederek vakfindan dönüp mülküne reddini murad etti. Buna binaen Vezîr-i mûmâileyh eimme-i müctehidînden tecvîz edenin mezhebi üzre vakfettim demekle vakfin lüzumunu iddia edince, bâlâda tevki'i yazılı mezbur hâkim sıhhat ve lüzumuna hüküm ve tescil-i şer'i ile tescîl etti. Bu suretle mezbûr vakıf, s1hhat ve in'ikad şartlarını câmi've butlan ve fesâd-ı mûcibelerinden hali, mânilerden âri ve şer'-i şerifin nehci üzre cari ve kavânîn-i asliyye ve fer'iyyeye mutâbılk olarak sahîh ve şer'î ve müebbet bir vakuf ve sarih ve mer'i bir vaklf oldu."

\section{c. Tescil Tarihi}

Osman Ergin, vakfiyede geçen merhum Sinan el-Bennâ ifadesinden yola ç1karak bu şahsın Fatih Külliyesi’nin mimarı Atik Sinan olduğunu tespitle, Atik Sinan'ın vefat tarihinin 1471 olmasından ve vakfi tescil ettiren Mahmud Paşa'nın ikinci sadaret döneminin 1472-1473 yılları olmasından hareketle, vakfiyenin 1472-1473 yıllarında tanzim edildiği sonucuna varmaktadır. ${ }^{8}$

Vakfiye üzerinde yaptığımız incelemede, aşağıda Akarlar başlığı altında yer alan 8 numaralı akarda 52 dükkânın sınırının Mahmud Paşa Vakfı'ndan başlayıp merhum Usta Sinanüddin Vakfı'na kadar devam ettiği, ${ }^{9} 405$ numaralı akarda yer

6 Vakfiye, TİEM-2202, sr. $962-965$.

7 Vakfiye, TİEM-2202, sr. $965-968$.

8 Osman Ergin, Fatih Imareti, s. 13.

9 Vakfiye, TİEM-2202, sr. 45 - 46. 
alan at değirmeninin merhum Sinan el-Bennâ'nın (Mimar/Usta Sinan'ın) ${ }^{10}$ yetimlerine ait olduğu ifade edilmektedir. Burada bahsi geçen merhum Usta Sinanüddin ve merhum Mimar Sinan, Fatih Camii'nin mimarı olan Atik Sinan olup, mezar taşında yer alan kitabeye göre vefat tarihi 13 Eylül 1471'dir. ${ }^{11} \mathrm{Bu}$ durumda vakfiyenin en erken tarihi 13 Eylül 1471'dir. Vakfı tescil ettiren Sadrazam Mahmud Paşa'nın ikinci sadaret dönemi 1472- Kasım 1473 tarihleri arasındadır.

Son olarak Fatih'in bu vakfiyesinin, İstanbul'un binaları ve arsalarının mukataaya bağlanmasından sonra yapıldığı binaların sonunda mine'l-mukâtaat (mukataalıdır) ifadesinden anlaşılmaktadır. ${ }^{12}$ İstanbul ilk alındığında bütün binalar halka mülk olarak verilmişken, sonradan mülkiyet usulü kaldırılarak mukataaya bağlanmıştır. Bu vakfiyenin de o tarihten sonra tanzim edildiği anlaşılmaktadır. Mukataa usulüne geçilen tarih ise Mahmud Paşa'nın ikinci vezirliği dönemidir (1472-1473). ${ }^{13}$ Netice itibariyle farklı noktalardan yapılan incelemelerin tamam1, bu vakfiyenin en erken tarihinin 1472, en geç tarihinin Kasım 1473 olduğunu ortaya koymaktadır.

Evkaf Nezareti'nin, bu vakfiyenin tesciliyle ilgili vakfiyenin sonunda yer alan kaydı şu şekildedir:

“İstanbul sâdis (altınc1) vakfiye: 46

Hulâsâ-i Vakfiye: 2815

Kuyûd-ı vakfiye numarası: 6354

İşbu vakfiye, şûrâ-i evkâfin 26 Kânûnu'l-evvel sene 1331 (8 Ocak 1916) tarihli kararına müsteniden 21 Rebiülevvel 1334 (27 Ocak 1916) tarihinde sudur eden irâde-i âliye mucebince kayd ve tescîl knlınmıştır. Fî 4 Şaban el-muazzam 1337 (5 Mayls 1919) ve fí 4 Mayls 1335 (4 Mayls 1919)"14

Yukarıdaki tescil kaydından anlaşılacağ 1 üzere vakfiyenin Evkaf Nezareti siciline tesciline ilişkin olarak Evkaf Şurası 8 Ocak 1916'da karar almış, alınan karar padişahın 27 Ocak 1916 tarihli iradesi ile onaylanmıştır. Sicile kayıt işlemi ise 5 Mayıs 1919 tarihi itibariyle tamamlanmıştır. Cumhuriyet döneminde ismi Türk ve İslam Eserleri Müzesi olarak değişen Evkâf-1 İslamiye Müzesi'nin ilk olarak Süleymaniye Külliyesi'nde 1914 yılında kurulduğu, vakfiyenin tesciline ilişkin karar ve padişah iradesinin 1916 tarihli olduğu düşünüldüğünde, Osman

10 Vakfiye, TİEM-2202, sr. 518.

11 Zeki Sönmez, "Sinân-1 Atik", Türkiye Diyanet Vakfi İslam Ansiklopediisi (DİA), c. 37, s. 228.

12 Ergin, Fatih Imareti..., s. 13.

13 Ergin, Fatih Imareti..., s. 14.

14 Vakfiye, TİEM-2202, sr. 982-987 (son 6 satır). 
Ergin tarafindan ifade edilen vakfiyenin Fatih'in sandukasından Evkaf Nezareti’ne bağlı olan Evkâf-1 İslamiye Müzesi'ne gönderilmiş olduğu görüşü kuvvet kazanmaktadır.

\section{Vakfiyede Yer Alan Hayır Müesseseleri ve Şartları}

Vakfiyede, fethi takiben Fatih Sultan Mehmed'in bunca nimetin şükrü olarak ve nimetlerin artması duasıla müzeyyen, latif kiliseleri medrese ve mescitlere dönüştürdüğü, sonra da Hz. Peygamber'in "her kim Allah rızası için bir mescit bina ederse Allah onun için cennette bir ev bina eder" mealindeki hadis-i şerifi ile amel ederek yeni mescitler bina etmeyi arzu ettiği ifade edilmekte ve bu vakfiyede sayılan hayır müesseselerinin bu düşüncelerle yaptırıldığı, vakfedildiğ anlatılmaktadır.

Vakfiyede hayır müesseselerinin anlatıldığı baş kısımda Fatih Camii, Sahn-1 Seman Medreseleri, Ayasofya Camii, Galata Camii ve Debbağlar Mahallesi'nde eskiden bimarhâne olarak bilinen Mâristan (Darüşşifa) sayılmaktadır. Vakfiyede hayır müesseselerinde çalışacak görevlilerin ve tahsisatların yer aldığı son kısımda ise, az önce sayılan müesseselerle birlikte Silivri Camii görevlileri de düzenlenmekte, Debbağlar Mahallesi'ndeki Darüşşafa'ya bağlı tabhanenin görevlileri ve ücretleri belirlenmektedir.

Vakfın diğer vakfiye nüshalarında geçen hayır müesseseleri en geniş haliyle;

- Fatih'in Bizans yapılarından dönüştürüp vakfettiği Debbağlar Mahallesi'ndeki Mâristan (darüşşifa), Ayasofya, Zeyrek, Galata, Silivri, Eski İmaret ve Kalenderhane Camileri,

- Fatih'in bizzat kendisinin yaptırdığ Fatih Külliyesi ${ }^{15}$ birimleri olan Fatih Camii, Sahn-1 Seman Medreseleri, Tetimme Medreseleri, Kütüphane, Darüşşifa, İmaret, Ayasofya'ya bitişik Darüttalim ile Vefa Camii ve Rumeli Hisarı (Kulle-i Cedide) Camii'nden oluşmaktadır. Aşağıdaki tabloda vakfın diğer vakfiye nüshalarında geçen en geniş hayır müesseseleri ile üzerinde çalıştığımız vakfiyede yer alan hayır müesseseleri yer almaktadır.

15 Fatih Külliyesi’yle ilgili geniş bilgi için bkz. Fahri Unan, Kuruluşundan Günümüze Fâtih Külliyesi, Ankara, Türk Tarih Kurumu Yayınları, 2003. 
Tablo 1: Fatih Külliyesi ve Ayasofya-i Kebir Vakfi'na ait vakfiyelerde geçen hayır müesseselerinin en geniş hali ve incelenen vakfiyedeki hayır müesseseleri

\begin{tabular}{|c|c|c|c|c|c|c|c|c|c|c|c|c|c|c|c|c|}
\hline 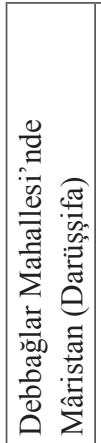 & 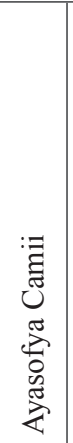 & 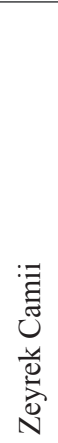 & 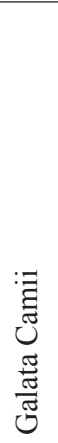 & 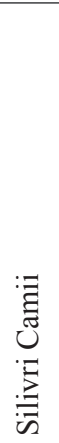 & 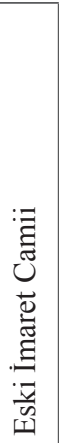 & 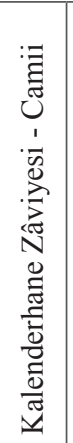 & 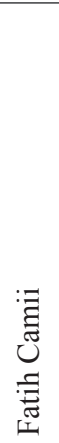 & 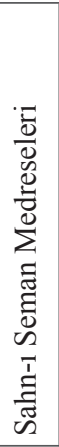 & 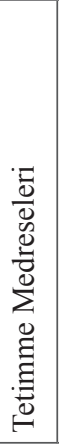 & 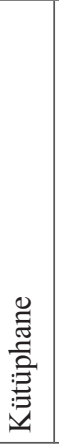 & 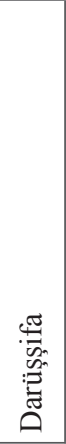 & 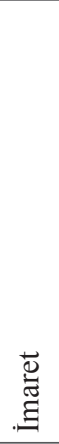 & 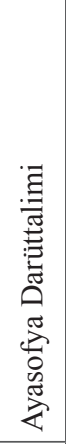 & 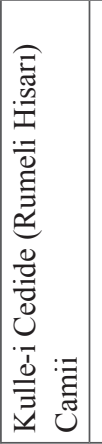 & 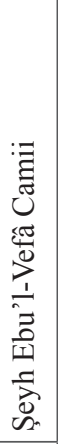 & 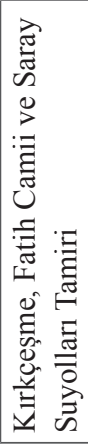 \\
\hline$\checkmark$ & $\checkmark$ & - & $\checkmark$ & $\checkmark$ & - & - & $\checkmark$ & $\checkmark$ & - & - & - & - & & - & - & $\checkmark$ \\
\hline
\end{tabular}

Tablodan anlaşılacağ 1 üzere, üzerinde çalıştığımız vakfiyede, Fatih Külliyesi ve Ayasofya-i Kebir Vakfı'na ait olduğunu kesin olarak bildiğimiz Zeyrek, Eski İmaret ve Kalenderhane camileri; Fatih Külliyesi'nin tetimme medreseleri, kütüphane, darüşşifa ve imaret birimleri; Ayasofya'ya bitişik darüttalim, Rumeli Hisarı Camii ve Şeyh Vefa Camii bulunmamaktadır. Buna mukabil, diğer hiçbir vakfiye nüshasında yer almayan Debbağlar Mahallesi'ndeki darüşşifa ve ona bağlı aşevi bu vakfiyede düzenlenmiş bulunmaktadır.

Aynı vakfa ait farklı vakfiye nüshaları arasındaki farklılıklar, literatürde hangi vakfiyenin asıl nüsha olduğu konusunda değişik görüşlerin ortaya çıkması sonucunu doğurmuştur. Belirtmek gerekir ki, Fatih Külliyesi ve Ayasofya-i Kebir vakfiyla ilgili tüm vakfiye nüshaları yayımlanmış değildir. Bu sebeple tüm vakfiye nüshalarını birlikte değerlendirip kesin bir kanaate varılması mümkün olamamıştır. Tüm vakfiye nüshalarının çevirisi yapılıp ilmi usullerle değerlendirildikten sonra bu konu açıklığa kavuşturulabilecektir.

\section{Fatih Cami Görevlileri ve Tahsisatları}

Fatih Camii görevlileri, görevleri, ücretleri ve tahsisatları vakfiyenin 906-924 satırları arasında belirlenmektedir. Buna göre Fatih Camii görevlileri şu şekildedir:

Hatip: Camide âlim, ilmiyle amel eden, güvenilir, fakih, kötülüğe meyl etmeyecek bir hatip görev yapacaktır. Hatip, selef-i salihinden ve Peygamber Efendimizin hutbesinden tevarüs edildiği gibi hutbe okuyacaktır. Aylık 1.000 dirhem ücret alacaktır.

İmam: Salih, takva sahibi, namazın şartlarını, adabını, müstehaplarını ve erkânını bilen, mütedeyyin, adil ve İmam-1 Azam hazretlerine mensup (Hanefi 
mezhebinden), bu mezhebin gereklerini bilen iki imam camide görev yapacaktır. Her birine 10'ar dirhemden günlük 20 dirhem ücret ödenecektir.

Baş Hâfız: Kıraat ilminde maharetli, yedi tür kıraati ve bunların meşhur olan füralarını, yedi şeyhin ve ravilerinin vücuh-1 ihtilaflarını bilen, devir okuyan hafızların hatalarını düzeltebilecek ve onlara yardımcı olabilecek bir kişi Başhafız olarak görevlendirilecek, hizmeti karşılığında günlük 8 dirhem ücret alacaktır.

Hâfiz: Camide, tecvit ve tertil ehli olan 9 hafiz görev yapacaktır. Bunlar her Cuma camide hazır olup, Kur'ân-1 Kerim'den kendilerine âsân geleni okuyacaklardır. Her biri günlük 5 'er dirhemden toplam 45 dirhem ücret alacaktır.

Hâfiz veya İlim Ehli 20 Kişi: Hafızlardan vesair ilim ehlinden 20 kişi daha camide görevli olacaktır. Bunlar camide her gün Kur'ân-1 Kerim'in yüzünden birer cüz okuyacaklardır. Okuma sırasında konuşmayıp sabır ve tertil üzere, harfleri karıştırmadan, Kur'ân-1 Kerim'in şânına yakışır şekilde okuyacaklardır. Her birine günlük 2'şer dirhemden toplam 40 dirhem ücret ödenecektir.

Muarrif: Salih bir kişi camide her namazdan sonra muarriflik görevini yerine getirecek, Allah’tan mağfiret dileyecek, hizmeti karşılığında günlük 6 dirhem ücret alacaktır.

Müezzin: Camide 10 müezzin görev yapacaktır. Her birine 5'er dirhemden günlük toplam 50 dirhem ücret ödenecektir. Müezzinler farz namazların vakitlerini bilecekler, minare üzerinde lahin ve teganni etmeksizin vakti müminlere ilan edecekler, güzel eda ile Müslümanları ibadete davet edeceklerdir.

Kayyım: Caminin 6 kapısını kapatıp kilitlemek, sergilerini sermek, süpürüp temizlemek görevlerini yapmak üzere 6 kayyım görev yapacaktır. Her birine 5'er dirhem olmak üzere günlük 30 dirhem ücret ödenecektir.

Mühellil (Kelime-i Tevhidhân): Yirmi kişi kelime-i tevhîdhan olarak görev yapacak ve günde yetmiş bin kere kelime-i tevhîd okuyacaklardır. Yani her biri günde 3.500 kere "Lâ ilâhe İllallah" diyecek, "lâ" harfini çekerek okuyacaklardır. Her birine günlük 1'er dirhem, reislerine 3 dirhem verilecek, böylece günlük toplam 22 dirhem ücret ödenecektir.

Salavathân: Camide 10 kişi de salavathan olarak görev yapacaktır. Her biri günlük 1.000'er kere Nebi Aleyhisselam'a Salavât-1 Şerife okuyacaktır. Her birine günlük 1'er dirhem ücret ödenecektir.

Kandilci: Camide 2 kandilci hizmet verecek, her birine 5'er dirhem olmak üzere günlük 10 dirhem ücret ödenecektir. 
Saatçi (Muvakkit): Bir saatçi görevlendirilecek ve hizmeti karşılığında günlük 15 dirhem ücret ödenecektir.

Suyolu Meremmetçisi: Suyolları tamiri için 2 kişi görevlendirilecek, her birine 5'er dirhemden günlük 10 dirhem ücret ödenecektir.

Yağ ve Hasır Tahsisatı: Caminin kandil yağı ihtiyacı için günlük 5 dirhem, hasır ihtiyacı için dünlük 3 dirhem tahsis edilmiştir.

\section{Sahn-ı Seman Medreseleri (Sekiz Medrese), Görevlileri ve Tahsisatları}

Vakfiyede Sahn-1 Seman Medreseleri şöyle anlatılmaktadır: (Fatih), caminin (Fatih Camii) şerefini, medreselerle ve onlarda tahsil edilen ilimlerle daha da arttırdı. Caminin etrafında ilim tedrisi için bina ettiği 8 yüksek medreseyle camiyi süsledi. Öyle ki, Cenabıhak bu medreseleri, ilim talebiyle gelenlere baki bir Cennet, bekâr fakihlerin meskun olacağ 1 , takva ve kerem sahiplerinin iltica edip vatan edineceği bir sığınak kıldı. Fatih bu medreseleri muhakkik, muhlis, müfîd, müstefid, metefakkih, muallim ve müteallim müderrislere vakfetti (sr. 24-26).

İncelemekte olduğumuz vakfiyelerde, Sahn-1 Seman Medreseleri'nin hemen yanında ve paralel olarak uzanan Tetimme Medreseleri'nden bahsedilmemektedir. Oysa sonraki tarihli vakfiyelerde Tetimme Medreseleri de Fatih Külliyesi'nin bir birimi olarak düzenlenmekte, görevlileri, talebeleri, ücretleri hakkında şartlar bulunmaktadır.

Vakfiyenin 899-906. satırlarında Sahn-1 Seman Medreseleri'nin görevlileri, ücretleri, öğrencileri ve tahsisatları belirlenmektedir.

Müderris: Sekiz medreseden her birine birer müderris görevlendirilecektir. Bu müderrisler takva sahibi, iffetli, şer'i ve akli ilimlerde âlim, meselelerin halline ve şüphelerin ortadan kaldırılmasına kadir, rivayet ve dirayetlerine inanılır, güvenilir kişiler olacaktır.

Caminin iki yanında bulunan Akdeniz ve Karadeniz Medreseleri’nin dört köşesinde bulunan 4 medresede ders veren müderrislerin her birine günlük 50 'şer dirhem ücret verilecektir. Ortada kalan medreselerde ders veren müderrislere ise günlük 40'ar akçe ücret verilecektir.

Muîd: Muid, medreselerde müderrisin verdiği dersi talebelere "tekrarlayan" anlamına gelen, öğretim elemanlarına verilen isimdir. Vakfiyeye göre sekiz medresenin her birinde birer muid görev yapacaktır. Muidler temiz halli, zeki ve erbabı tahsilin (müderrislerin) okuttuğu dersleri talebeye tekrar etmeye muktedir kişiler olacaklardır. Medrese muidlerinden her birine günlük 5 'er dirhem ücret verilecektir. 
Medrese Talebelerine Burs Tahsisatı: Medrese talebelerine günlük otuz dirhem ödeme yapılacaktır. Burada her bir talebeye otuzar dirhem değil, talebelerin tamamına 30 dirhem ödenmesi şart edilmektedir, yani 30 dirhem medreselerdeki toplam talebe sayısına bölünerek talebe başına ödeme yapılacaktır.

Bevvâb: Her medresede bir bevvap görev yapacak olup, toplamda 8 bevvap medreselerde hizmet verecektir. Her birine 2'şer dirhem günlük ücret ödenecektir.

Hademe: Her medresenin tuvaletinde bir hademe olmak üzere 8 medresede 8 hademe görev yapacak, hizmetleri karşıllı̆ında kendilerine günlük 2'şer dirhem ücret ödenecektir.

Hâfiz-ı Kütüb: Her dört medresede bir olmak üzere sekiz medresede iki kişi, vakfedilen kitapları korumak için hâfız-1 kütüp olarak görevlendirilecek, her birine günlük 5'er dirhem ücret ödenecektir. Vakfiyede, ayrı bir kütüphane binasından bahsedilmemekte, Sahn-1 Seman Medreseleri görevlileri arasında her dört medrese için 1 hâfız-1 kütüp olmak üzere 8 medrese için toplam 2 hâfız-1 kütüp görevlendirilmektedir.

Medreselerin Ë̈itim ve Tatil Günleri: Gerek müderris ve muidler ve gerekse öğrenciler, tatil günlerinin dışında her gün medreseye gelip derslere katılacaktırlar.

\section{Ayasofya Camii, Görevlileri ve Tahsisatları}

İncelemiş olduğumuz vakfiyede hayratların yer aldığı baş kısımda, Fatih Sultan Mehmed tarafindan kiliseden camiye çevrilerek vakfedilen iki cami yer almaktadır. Bunlar Ayasofya ve Galata (günümüzde Karaköy'deki Arap Camii) camileridir. Vakfiyede şöyle tarif edilmektedirler:

Kıymetli taşlarla süslü, müzeyyen, vasıflarıyla kemale ermiş, temizlik ve güzellikte misli ve benzeri görülmemiş, en güzel bahçelerden daha güzel, içinde sur gibi dikilen sütunlar bulunan iki kiliseyi vakfetti. Bunlardan birisi, İstanbul'un göbeğinde bulunan, Ayasofya ismiyle bilinen ve şöhretinden dolayı ayrıca sınırlarının belirlenmesi gerekmeyen kilisedir. Diğeri ise Galata'da bulunan, Samike (Samiko ?) Manastırı diye bilinen, iki taraftan anayol ve diğer iki taraftan Efrenc Nikrus Kazi'nin evleriyle sınırlı olan kilisedir. Fatih bu iki kiliseyi cuma, bayram ve farz olan beş vakit namazın kılınması, Cenab-1 Hakk'ın oralarda tesbih olunup isminin zikr olunması için vakfedip camiye çevirdi (sr. 27-32).

Vakfiyenin 923-925. satırları arasında yapılan düzenlemeye göre Ayasofya Camii'nde vazife yapacak görevliler şu şekildedir:

Hatip: Fatih Camii hatibi için aranan sıfatlara sahip 1 hatip görevlendirilip, hizmeti mukabilinde kendisine günlük 20 dirhem verilecektir. 
Imam: Fatih Camii imamları için aranan sıfatlara sahip 1 imam görevlendirilecek, hizmeti karşılığında kendisine 5 dirhem ücret verilecektir.

Başhâfiz: Fatih Camii'nde görev yapacak başhâfizda aranan sıfatlara sahip 1 başhâfız görevlendirilecek, görevi karş1lığında günlük 7 dirhem ücret verilecektir.

Hâfız: Fatih Camii'nde görev yapacak hâfizlarda aranan sıfatlara sahip 9 hafız görevlendirilecektir. Hizmetleri karşıllı̆ında her birine günlük 5'er dirhemden toplam 45 dirhem ücret verilecektir.

Hafiz ve Ulemadan 20 Cüzhan: Hafızlardan ve salih âlimlerden 20 kişi görevlendirilecek, bunlar Ayasofya Camii'nde hazır olacaklar ve her biri Kur'an-1 Kerim'den günlük birer cüz okuyacaklardır. Hizmetleri karşılığında her birine günlük 2'şer dirhemden toplam 40 dirhem ücret ödenecektir.

Müsebbih ve Mühellil: Ayasofya Camii'nde 14 kişi müsebbih (tesbih eden) ve mühellil (Kelime-i Tehlil getiren) görevlendirilecektir. Her biri günlük 5.000'er kere "Lâ ilâhe İllallah" diyerek günde 70.000 kere kelime-i tevhîd okuyacaklardır. Her birine günlük 1'er dirhem, reislerine ise üç dirhem olmak üzere toplam 16 dirhem ücret ödenecektir.

Muarrif: Fatih Camii muarrifinde aranan sifatlara sahip 1 muarrif Ayasofya'da görev yapacak ve vazifesi karşıllğında kendisine günlük 7 dirhem ücret verilecektir.

Müezzin: Fatih Camii müezzinlerinde aranan şartlara sahip 6 müezzin görevlendirilip, her birine günlük 6'şar dirhemden toplam 36 dirhem ücret verilecektir.

Kandilci: Fatih Camii kandilcilerinde aranan özelliklere sahip 2 kandilci görevlendirilecek, her birine günlük 5'er dirhemden toplam 10 dirhem ödenecektir.

Saatçi: Camide bir saatçi görevlendirilecek, günlük 10 dirhem ücret ödenecektir.

Kayyım: Ayasofya Camii’nde 4 kayyım görev yapacak, hizmetleri karşı1ığında her birine 5'er dirhemden toplam 20 dirhem ücret ödenecektir.

Meremmetçi: Tamir, bakım hizmetleri için görevlendirilecek 2 meremmetçiye günlük 5'er dirhem ücret verilecektir.

Muallim: Yetimleri okutmak üzre bir muallim görevlendirilecek ve günlük 6 dirhem ücret verilecektir.

Sonraki tarihli vakfiyelerde, Ayasofya Darüttalimi hayır müessesesi olarak düzenlenerek görevlileri ve tahsisatı belirlenmektedir. İncelemekte olduğumuz vakfiyede ise Ayasofya Darüttalimi'nden bahis bulunmamakta, Ayasofya Camii görevlileri sayılırken yetim çocukları okutmak üzere 1 muallim görevlendirmesi 
yapılmaktadır. Dolayısıyla bu vakfiye için Ayasofya Darüttalimi ayrı bir başlık altında değerlendirilmemiş, vakfiyedeki tasnife uyularak Ayasofya Camii'ne bağ11 bir hizmet olarak ele alınmıştır.

Saka: İki saka görev yapacak ve kendilerine günlük 2'şer dirhemden toplam 4 dirhem verilecektir.

Bezzazistan (Kapalıçarşı) İçin 4 Bekçi: Bezzazistanı muhafaza içün 4 kişi bekçi olarak görevlendirilecek ve bu kişilerin her birine günlük 2'şer dirhem olmak üzere toplam 8 dirhem ücret ödenecektir.

Kapalıçarşı bekçileriyle ilgili bu düzenleme, Ayasofya Camii görevlileri ve tahsisatları içerisinde yer almaktadır. Vakfiye aslındaki düzenlemeye sadık kalınarak cami görevlisi olmamalarına rağmen Ayasofya Camii görevlileri arasında değerlendirilmiştir.

Kandil Yağı ve Hasır Tahsisatı: Caminin kandil yağı ihtiyacı için günlük 5 dirhem, hasır ihtiyacı için ise günlük 5 dirhem ödeme yapılacaktır.

\section{Galata Camii (Arap Camii)}

Vakfiyede, Ayasofya ile birlikte kiliseden camiye çevrilen ikinci yapı, Galata'da bulunan ve (Samiko ?) Manastırı diye bilinen kilisedir. Burası da, cuma, bayram ve beş vakit farz namazların kılınacağı cami olarak Fatih tarafından vakfedilmiştir (sr. 27-32). Günümüzde Karaköy'de Arap Camii adıyla hizmet vermeye devam etmektedir.

Vakfiyede Galata Camii görevlileri 936-939. satırları arasında şu şekilde belirlenmiştir:

Hatib: Fatih Camii hatibi için belirlenen şartlara uygun bir kişi Galata Camii’nde hatip olarak görevlendirilecek ve hizmeti karşıllğında kedisine günlük 8 dirhem verilecektir.

Imam: Fatih Camii imamlarında aranan şartları taşıyan bir kişi Galata Camii’nde imam olarak görevlendirilecek ve hizmeti karşılığında günlük 5 dirhem alacaktır.

Hâfiz: Camide 3 hâfız görev yapacak ve hizmetleri karşıllı̆ında günlük 9 dirhem ücret alacaklardır. Reisleri günlük 4 dirhem ücret alacaktır.

Müezzin: Camide 2 müezzin görev yapacak, her birine günlük 3'er dirhem, ikisine günlük toplam 6 dirhem ücret ödenecektir.

Kayyım: Camide 2 kayyım görev yapacak, her birine günlük 3'er dirhem, ikisine günlük toplam 6 dirhem ücret verilecektir. 
Kandilci: Caminin kandilcisi olarak 1 kişi görev yapacak, günlük 3 dirhem ücret alacaktır.

Muarrif: Caminin muarrifi olarak 1 kişi görev yapacak, günlük 4 dirhem ücret alacaktır.

Kandil Yağı ve Hasır Tahsisatı: Caminin kandil yağı ve hasır ihtiyacı için vakıftan günlük 2 dirhem tahsisat ayrılmıştır.

\section{Silivri Camii, Görevlileri, Tahsisatları}

Silivri Kalesi'ndedir ve kiliseden camiye çevrilip vakfedilmiştir. Vakfiyenin hayır müesseselerinin sayıldığı baş kısımda ismi geçmemektedir. Ancak, vakfın vazifelilerinin ve ücretlerinin belirlendiği son kısımda Galata Camii görevlilerinden sonra Silivri Camii'nin görevlileri ve görevleri belirlenmektedir.

$\mathrm{Bu}$ vakfiyede belirtilmemekle birlikte, Silivri Camii'nin kiliseden camiye çevrilip Fatih Sultan Mehmed tarafından vakfedildiği, incelediğimiz diğer vakfiyelerde açıkça söylenmekte, Fatih tarafından kiliseden camiye çevrilip kendi vakfına bağlanan 6 camiden biri olduğu görülmektedir.

Vakfiyede cami görevlileri ve cami tahsisatları 939-940. satırları arasında aşağıdaki şekilde düzenlenmiştir:

Hatib: Silivri Camii için 1 hatip görevlendirilecek ve günlük 2 dirhem ücret ödenecektir.

Imam: Camide 1 imam görev yapacak ve günlük 2 dirhem ücret alacaktır.

Müezzin: Caminin müezzini olarak görevlendirilecek 1 kişi, günlük 2 dirhem ücret alacaktır.

Muarrif: Muarrif görevini yerine getirecek bir kişiye günlük 1 dirhem ücret ödenecektir.

Kayyım: Camide 1 kayyım görev yapacak ve günlük 1 dirhem ücret alacaktır.

Kandil Yağı ve Hasır Tahsisatı: Caminin kandil yağı ve hasır ihtiyacı için vakıftan günlük 1 dirhem tahsisat yapılmıştır.

\section{Debbağlar Mahallesi'nde Darüşşifa (Mâristan/Bimarhâne), Görevli- leri ve Tahsisatları}

\section{a. Darüşşifa'nın Bulunduğu Yer}

Hayrat bakımından bu vakfiyenin diğer vakfiyelerden en farklı yanı, sadece bu vakfiyede yer alan, diğer vakfiyelerde adı geçmeyen Debbağlar Mahallesi'ndeki mâristanın düzenlendiği tek vakfiye olmasıdır. Vakfiyenin baş kısmında 
hayratın sayıldığı bölümde eskiden Bimarhâne olarak bilinen Debbağlar Mahallesi'ndeki Mâristan'dan bahsedilmekte, vazifelilerin düzenlendiği son kısmında da yukarıda bahsedilen darüşşifanın / mâristanın görevlileri belirlenmektedir.

Bu durum, Fatih Külliyesi'nde var olan Fatih Darüşşifası'yla Debbağlar Mahallesi'ndeki Mâristan'ın (Darüşşifa'nın) karıştırılmasına yol açmaktadır. Ancak incelemekte olduğumuz bu vakfiyede düzenlenmiş olan Debbağlar Mahallesi'ndeki Mâristan (Darüşşifa) ile Fatih Külliyesi'ndeki Darüşşifa birbirinden farklı iki sağlık tesisidir.

"Debbağlar Mahallesi'nde bulunan ve dört taraftan miri araziyle sınırlı olan, eskiden Bimarhâne adıyla bilinen büyük binayl, ecir ve sevap kazanmak içün rızâ-i İlâhi'yi kastederek Hastane yaptı (...). Mücir-i azap, yani azaptan kurtaran Allah tarafindan sevaba, korunmanin en güzeline, hasenatın en nemalısina nail olmak için (...) onu (Mâristan1) hastalara, malullere, kötürümlere, ilaca ve beden sağlığına muhtaç olanlara vakfetti” (sr. 33-36).

Vakfiyede geçen mâristanın bulunduğu Debbağlar Mahallesi'nin nerede olduğu hususunda Ekrem Hakkı Ayverdi şu bilgiyi vermektedir: ${ }^{16}$ "V.I'de $e^{17}$ Unkapanı batısındaki Muhyiddin Kocavi Mescidi Mahallesi civarında gösterilir. T.D. - $457 \mathrm{de}^{18}$ hudutlar münasebetiyle iki defa ismi varsa da, geniş sahaya şamil bir hüviyet arzetmiyor. Mescidi de yoktur. Bu seplerle 87 no.lu (Kara Şems Mescidi Mahallesi) hakkındaki istidratlarımı bu mahalle için evveliyetle varittir. Diğer kaynaklarda ismi geçmediğinden Fatih Devri sonuna tam teşekküllü mahalle olarak erişememiştir. Bu sebeple haritada gösterilmeyecektir."19

İncelediğimiz vakfiyede akarlar bölümünde geçen Debbağlar Mahallesi’yle ilgili kısma baktığımızda, 332 numaralı akarda "Çömlekçiler çarşısı karşısında bulunan, kısmen bitişik ve kısmen ayrı on üç hücrenin tamamı. Bunların sınırı, yukarı taraftan Odun Kapısı'ndan başlayıp Debbağlar Mahallesi'nde bulunan

16 Ekrem Hakkı Ayverdi, Fatih Devri Sonlarında Ístanbul Mahalleleri, Şehrin İskânı ve Nüfusu, Ankara, Vakıflar Umum Müdürlüğü Yayınları, 1958, s. 17.

17 Ayverdi, Fatih Devri Sonlarında İstanbul Mahalleleri... kitabının 10. sayfasındaki 15 numaralı dipnotta V.1'in 1. Vakfiye olduğunu, 6. sayfasında da makalenin kaynakları arasında yer alan V.1'in, incelemekte olduğumuz Türk ve İslam Eserleri Müzesi'ndeki vakfiye olduğunu ifade etmektedir.

18 Ayverdi, Fatih Devri Sonlarında İstanbul Mahalleleri... kitabının 10. Sayfasındaki 15 numaralı dipnotta T.D. kısaltmasının 1546 tarihli İstanbul Vakıfları Tahrir Defteri olduğunu ifade etmektedir. Bahsi geçen tahrir defteri için bkz. Ömer Lütfi Barkan - Ekrem Hakkı Ayverdi, İstanbul Vakıfları Tahrir Defteri 953 (1546) Tarihli, İstanbul, İstanbul Fetih Cemiyeti İstanbul Enstitüsü Yayınları, 1970.

19 Ekrem Hakkı Ayverdi, Fatih Devri Sonlarında ..., s. 2. 
Rumi Vasiliko'nun hücresine doğru giderek Kapanhanı Kapısı'nda sona erer. Bu hücreler, kemerler tabir olunur ve bunların cümlesi sura bitişik ve Sultan'a ait dükkânlardır" ifadesi yer almaktadır (sr. 443-445).

333 numaralı akarda, "Mezbur mahallede bulunan ve Rumi Vasilikoya ait ve ön taraftan yol ile sinırlı ve kal'anın suruna bitişik mukataalı dükkânın tamamı", 334 numaralı akarda "Kapan kapısı yakınlarında bulunan ve şöhretine binaen tahditten müstağni bergozun tamamı, 335 numaralı akarda "Adı geçen kapı yakınlarında bulunan ve sura bitişik olup eski kemerler tabir olunan hali hücrelerin tamamı" denilmektedir (sr. 445-447).

Yukarıdaki tariflerden anlaşılacağı üzere bimarhânenin bulunduğu Debbağlar Mahallesi, Kapanhanı (Unkapanı) ile İstanbul'un Haliç tarafındaki sur kapılarından olan Kapan Hanı Kapısı arasında bir konumda bulunmaktadır. Bu tespit, Ekrem Hakkı Ayverdi'nin Unkapanı tespitini teyit etmektedir.

1600 tarihli İstanbul Vakıfları Tahrir Defteri'nde, ${ }^{20} 105$ numaralı mahalle olan Hazret-i Şeyh Muhyiddin el-Kocevi Mescidi Mahallesi'nde, Debbağlar Mahallesi'yle ilgili şu ifadeler yer almaktadır:

1774 numaralı vakıf: Musa Bey bin Abdullah Vakfi

Asl-ı vaklf (vakfin akarlarl)

3 dükkân: Debbağlar Mahallesi'nde, adı geçen vakıf ve yol ile sinırlıdır.

Hane ve dükkân: Debbağlar Mahallesi'nde, adı geçen vakıf ve yol ile sinırlıdır.

Hane ve dükkân: Debbağlar Mahallesi'nde, adı geçen vaklf, yol, yukarıdaki han ve dükkânla sinırlıdır.

Hane: Debbağlar Mahallesi'nde, Ömer Fakih ve Mevlana Muhyiddin mülkleri ve adı geçen vakıf ile sinırlıdır.

Hane: Debbağlar Mahallesi'nde, Ömer Fakih mülkü, kabirler, harem-i mescid ve adı geçen vakıfla sınırlıdır.

Hane: Debbağlar Mahallesi'nde, kabirler, harem-i mescit ve yol ile sinırlıdır.

Buradan anlaşılacağı üzere, Musa Bey bin Abdullah Vakfi'na ait hane ve dükkânlar Şeyh Muhyiddin Kocevi Mahallesi'ndedir ve mahalleye ismini veren mescitle sınırları bulunmaktadır. Debbağlar Mahallesi denilen yer de, 1600 yılı itibariyle Şeyh Muhyiddin Kocevi Mahallesi sınırları içerisinde, bu mescidin yakınında ve sınırındadır. Şeyh Muhyiddin Kocevi Mahallesi, İstanbul'un 12

20 Mehmet Canatar, İstanbul Vakıfları Tahrir Defteri 1009-(1600), İstanbul, İstanbul Fetih Cemiyeti Yayınları, 2004. 
nahiyesinden biri olan Sultan Mehmed Han Camii (Fatih Camii) Nahiyesi'ne bağlıdır. Ayverdi'nin yayımladığı İstanbul Mahalleleri haritasında, Unkapanı Mahallesi'yle Muhyiddin Kocevi Mahallesi'nin yan yana ve günümüzde Unkapanı'ndan Haliç'e doğru uzanan mevkide yer aldığg görülmektedir. ${ }^{21}$ Tüm bu bilgiler birlikte değerlendirildiğinde ve Unkapanı bölgesinin Bizans döneminde de yoğun yerleşim yeri olduğu düşünüldüğünde, vakfiyede geçen Debbağlar Mahallesi'ndeki Bimarhâne'nin günümüz itibariyle Unkapanı'ndan Haliç'e doğru uzanan bölgede bulunduğu tamamen netlik kazanmaktadır. Ancak mâristanın tam yeri ve binanın tarihi günümüzde bilinememektedir. ${ }^{22}$

Fatih İstanbul'u aldığında İstanbul'da sadece Aristo hastanesinin (Debbağlar Mahallesi'ndeki mâristan) var olduğu ifade edilmektedir. ${ }^{23}$ Fatih Külliyesi Darüşşifası yapılana kadar bu yapı İstanbul'un tek hastanesi olarak hizmet vermeye devam etmiştir. ${ }^{24} \mathrm{Bu}$ durumda Fatih'in biri Debbağlar Mahallesi'nde, diğeri Fatih Külliyesi'nde olmak üzere iki vakıf hastanesi bulunmaktadır. ${ }^{25}$ Fatih'in diğer vakfiyeleriyle birlikte değerlendirildiğinde, Aristo Bimarhânesi’nin sadece bu vakfiyede yer almasını şöyle yorumlayabiliriz. Fatih, İstanbul fethedildiğinde tek hastane olan Debbağlar Mahallesi'ndeki Aristo Bimarhânesi'nde sağlık hizmetlerini devam ettirmiş, bu tesisi vakfına katarak tahsisatlarını belirlemiştir. Fatih Darüşşifası tamamlandıktan sonra zaman içerisinde Aristo hastanesi kapatılıp Fatih Darüşşifası'na taşınmış olmalıdır. ${ }^{26}$ Böylece hastane hizmeti Fatih Darüşşifası'na nakledildiğinden, II. Bayezid döneminde istinsah edilen vakfiyelerde Aristo Bimarhânesi'nden bahsedilmemektedir. Anlaşıldığı kadarıyla sonradan bu Bimarhâne ortadan kalkmış ve günümüze ulaşmamıştır.

Mâristanın hizmet şartları, görevlileri ve Mâristana bağlı tabhane görevlileri vakfiyenin 941-955. satırları arasında düzenlenmektedir.

21 Fatih devri sonlarında İstanbul mahalleleri haritası için bkz. Ekrem Hakkı Ayverdi, Fatih Devri Sonlarında..., s. 90.

22 Çiğdem Kafescioğlu, Constantinapolis / İstanbul, Pensilvania, The Pennyslvania State University Press, 2009, s. 230.

23 Bedi N. Şehsuvaroğlu, Türk Tip Tarihi, Bursa, 1984, s. 40; Seyran Aktaş, "XV. ve XVI. Yüzyıllarda Sultan Dârüşşifâları”, (Yayımlanmamış Yüksek Lisans Tezi), Gazi Üniversitesi S. B.E., Ankara, 2010, s. 35.

24 Namık Erkal, “İstanbul'da Erken Dönem Osmanlı Mimarisi”, Antik Çağdan XXI. Yüzyıla Büyük İstanbul Tarihi - Mimari, c. VIII, İstanbul, İstanbul Kültür A.Ş. Yayınları, 2015, s. 115.

25 A.Süheyl Ünver, Fatih Külliyesi ve Zamanı İlim Hayatı, İstanbul, İstanbul Üniversitesi Yayınlar1, 1946, s. 71. Ünver konuyu anlatırken vakfiyenin Arapça' dan mealen çevirisi olarak tırnak içerisinde yazdığı cümlede “... eskiden Aristo hastanesi olarak bilinen ...” ifadesini kullanmaktadır (s.70-71). Vakfiyenin ilgili sayfasına bakıldığında Aristo ifadesine rastlanılmamıştır. 


\section{b. Darüşşifa Tahsisatlart}

Vâkıf Fatih Sultan Mehmed Han, darüşşifada hastaların her tür ihtiyacının, darüşşifa doktorunun hastane ve hastalar için gerekli ve lüzumlu gösterdiği her türlü eşya ve hususun karşılanması için günlük 100 dirhem tahsis etmiştir. Bu 100 dirhemin 10 dirhemi sergi, yorgan, yatak, elbise ve bürünülecek şeylere, geri kalanı sair alet, edevat, ilaç ve eczaya harcanacaktır.

\section{c. Darüşşifa Görevlileri ve Ücretleri}

\section{Darüşşifa Nazırı}

Darüşşifada, nasıl iş yapacağını bilen, şiddet yoluna başvurmaktan çekinen, görevlerini en iyi şekilde yapan, yapması gerekenleri bir tarafa bırakmayan, hiçbir konuda ihmalkârlık göstermeyen bir kişi Darüşşifa Nazırı olarak görev yapacaktır. Hizmeti karş1lı̆ı̆nda günlük 10 dirhem ücret alacaktır.

Görüldüğü gibi darüşşifanın genel yönetimi Darüşşifa Nazırı tarafından yerine getirilmekte olup, darüşşifanın en üst yöneticisi konumundadır.

Tabip: Sanatında mâhir, teori ve uygulamayı bilen, feraset sahibi, belirtilere göre hastalığın sebeplerini ortaya çıkarma ve tedavi etmede isabetli davranabilen, hastalıklarda ve hastalıkların ortaya çıkaracağı marazlar konusunda çok tecrübeli, marazları ilaç ile tedavi hususunda çok deneyimli, gayet merhametli ve şefkatli bir doktor darüşşifada görev yapacak, hizmeti karş1lığında günlük 20 dirhem ücret alacaktır.

Cerrah: Cerrahlıkta işinin ehli ve işini çok iyi bilen bir kişi cerrah olarak darüşşifada görev yapacak ve günlük 5 dirhem ücret alacaktır.

Hademe: Tedavi olan hastalara şefkatli, onlara çok iyi bakan, onları temizlemek ve yıkamaktan çekinmeyen 2 kişi darüşşifada hademe olarak görev yapacaktır. Hizmetleri karşı1lığında her birine günlük 3'er dirhem olmak toplam 6 dirhem ücret ödenecektir.

\section{d. Darüşşifa Tabhanesi ve Görevlileri}

Vakfiyede Debbağlar Mahallesi'nde bulunan darüşşifadaki görevliler belirlendikten hemen sonra tabhane (aşevi) görevlileri ve ücretleri sayılmaktadır. İlk etapta bu durum bahsedilen tabhanenin Fatih imareti olabilme ihtimalini akla getirse de, darüşşifa görevlileriyle tabhane görevlilerinin art arda sayılması, arada herhangi bir geçiş cümlesi, belirtisi olmaması, Fatih Külliyesi’nin bir birimi olduğuna dair hiçbir ifade taşımaması karşısında, buranın Debbağlar Mahallesi'ndeki darüşşifaya bağl1, hastalara yemek hizmeti veren bir tabhane olduğu sonucunu ortaya ç1karmaktadır. Tabhane görevlileri vakfiyede şu şeklide belirlenmiş bulunmaktadır: 
Aşçı: Sanatında mahir ve her türlü yemeği pişirebilecek 2 aşçı görevlendirilecek, her birine günlük 3'er akçeden 6 akçe ücret verilecektir.

Kilerdar: Aşhanenin bütün alet ve edevatını korumak için bir kilerdar görevlendirilecek, hizmeti karşılığında kendisine günlük 4 dirhem ödenecektir.

Vekilharç: Emin ve kendine verilen hizmetleri yerine getirecek bir kişi vekilharç olarak görevlendirilecek, hizmet karşılığında günlük 4 dirhem alacaktır.

Kâtip: Gelir ve giderleri yazan, emin ve diyanet ehli bir kâtip görev yapacak ve günlük 4 dirhem ücret alacaktır.

\section{e. İlaç ve Tıbbi Malzemelerin Kullanım Şartlart}

Mâristanda bulunan bütün ecza, ilaç, şurup, gıda ve tedavide kullanılan eşyalar, doktorun emriyle, uygun gördüğü şekilde ve gösterdiği lüzum ile sarf olunacaktır. Hastane dışına verilmeyip, ancak dışarıda bunların bulunmadığı veya elde edilmesinin güç olduğu durumlarda dişarıya verilebilecektir (sr. 956).

\section{Hayır Hizmeti Şartı: Kırkçeşme, Fatih Camii ve Saray’a Giden Suyollarının Bakım ve Onarımı}

Vakfiyede Kırkçeşme ile Fatih Camii ve Saray'a bağlı suyolundan bahsedilmekte, fakat bu suyolunun vakfa ait olduğuna dair herhangi bir ifade bulunmamaktadır. Ancak, vakfiyede mütevellinin görevlerinin belirlendiği k1sımda vakıf gelirlerin sarf edileceği yerler öncelik sırasına göre belirlenirken, ilk sırada vakfa ait yerlerin tamir, bakım, onarım ve gerekirse yeniden yapım masraflarının karşılanması hükmü yer almaktadır. İkinci sırada iki suyolunun, yani Kırkçeşme isimli çeşmeye bağlı suyolu ile Fatih Camii ve saraya akan suyollarının tamir masraflarının karşılanması hükmü yer almaktadır. Diğer yandan, Fatih Camii ve Ayasofya Camii görevlileri arasında 2'şer kişi olmak üzere toplam 4 suyolu tamircisi yer almakta ancak bu görevlilerin yapacakları işler hakkında bilgi verilmemektedir. Tüm bunlar birlikte değerlendirildiğinde Fatih döneminde yaptırılan Kırkçeşme suyollarının Fatih'in vakfına dahil edilmediği, ancak hayır şartı olarak bu suyolunun tamir, bakım onarım masraflarının Fatih Sultan Mehmed Han Vakfı tarafindan karşılandığı sonucuna varılmaktadır. Bakım onarımı Fatih Sultan Mehmed Han Vakfı tarafından üstlenilen suyollarının Fatih Camii'ne, Fatih Camii yakınındaki Kırkçeşme'ye ve bu günkü İstanbul Üniversitesi ana yerleşmesinin bulunduğu Beyazıt'taki eski saraya bağlı olduğu düşünüldügünnde, Fatih Camii ve Ayasofya Camii kadrolarında yer alan suyolu tamircilerinin de bu suyollarının bakımında görev aldıklarını söylemek yanlış bir çıkarım olmayacaktır. 


\section{Vakfin Akarları}

Vakfin akarları vakfiyenin 36- 889. satırları arasında sayılmaktadır. Burada sayılan akarların önemli bir kısmının sonunda mukataalı olduğu belirtilmektedir.

Vakfiyenin 36-38. satırlarda vakfın akarlarına giriş cümleleri yer almakta ve uzun bir akar listesi başlamaktadır. 39-40. satırlarda vakfın ilk dört akarı olan 4 hamam yer almaktadır. 41-174. satırlarda (5-100 arası akarlar), özellikle Kapalı Çarşı ve etrafindaki hanlar, çarşılar, sur içerisindeki kapanlar, pazarlar ve birçok dükkânın bir arada bulunduğu akarlar ile Unkapanı ve Balat'ta bulunan büyük çaplı akarlar yer almaktadır. Bu kapsamda, Kapalı Çarşı civarında bulunan İplik Bükücüler, Bit Pazarı, Külahçılar Çarşısı, Kavaflar Çarşısı, Saraçlar Çarşısı, Hallaçlar Çarşısı, Bedesten etrafındaki dükkânlar, Yeni Bedesten (Bezistan / Bezzazistan / Kapalı Çarşı), Sultan Hanı (Yeni Han), Tavukçular Çarşısı, Bebbağlar (Dericiler) Çarşısı, Eski Bozahaneler, Bakırcılar Çarşısı, Eski Kervansaray, İplikçiler Çarşısı, Karamanlılar Çarşısı (Karaman Pazarı), Unkapanı, Yağhane, Salhane, Yemişkapanı, Balıkçılar Çarşısı, Balat Pazarı gibi şehrin en büyük ve en önemli çarşı pazarları ve dükkânları vakfiyenin bu kısmında Fatih Sultan Mehmed Han Vakfı'na ait akar olarak kayıtlı bulunmaktadır.

Vakfiyenin 175-580. satırlarında (101-465 arası akarlar), Sur içinde muhtelif mahallelerde bulunan ve çoğunluğu birer, ikişer dükkândan oluşan akarlar yer almaktadır. Bunların çok büyük kısmı mukataalıdır. 580-620. satırlarda (466-512 arası akarlar) Ayasofya Mahallesi'nde yer alan akarlar yer almaktadır. Buraya kadar sayılan akarların tamamı İstanbul Sur içindedir.

622-737. satırlarda (513-611 aras1 akarlar) Galata'da bulunan akarlar say1lmaktadır. Bu akarlar evler ve dükkânlardan oluşmaktadır. Bir kısmında Sultan'ın şahsına ait, bir kısmında ise mukataalı olduğu belirtilmektedir.

738-779. satırlarda (612-614 aras1 akarlar) vakfedilen köyler yer almakta, bu kapsamda Terkos Köyü, Eskihisar adıyla bilinen Loğoz, Eskoz ve Gelenkoz köyleri ve Silivri Kalesi arazisi sayılmaktadır.

779-869. satırlarda (615-707 arası akarlar) yine Sur içinde yer alan ve çoğunluğu dükkânlardan oluşan akarlar sayılmaktadır.

869-870. satırlarda Üsküdar'da akar olarak vakfedilen bir han yer almaktadır.

870-885. satırlarda, daha önce 738. satırdan itibaren kaydedilmiş olan Silivri Kalesi, aynı şekliyle mükerrer olarak yazılmış bulunmaktadır.

885-887. satırlarda, yukarıda sayılan akarların vakfedildiğine dair ifadeler yer almaktadir.

887-888. satırlarda Tahtakalede vakfedilen hamam yer almaktadır. 
888-889. satırlarda, İstanbul'da zimmilerden alınan cizyeden 200.000 dirhemin tahsis kabilinden olmak üzere vakfedildiği ifade edilmektedir.

Osman Ergin vakfiyede akar olarak 1130 ev, 2466 dükkân, 3 han, 54 değirmen, 57 oda, 26 mahzen, 4 hamam, 7 birgos, 2 kapan, 9 bahçe bulunduğunu aktarmaktadır. ${ }^{27}$ Vakfiyede yer alan akarları excel dosyası olarak hazırlayıp türlerine göre yeniden süzme yaptığımızda karşımıza aşağıdaki akar listesi çıkmaktadır:

- İstanbul'da 106 farklı noktada 910 adet ev (beyt). Ayrıca çok sayıda denilip adet belirtilmeyen evler de bulunmaktadir.

- 2.634 adet dükkân. Ayrıca bakkal dükkânları denilip sayısı belirtilmeyen dükkânlar da mevcuttur.

- İkisi Vasiliko Kapısı yakınında, biri Üsküdar'da 3 han.

- 67 adet değirmen.

- 74 oda (hücre). Ayrıca sayı belirtilmeden bir yerde hücreler, bir yerde de müteaddit hücreler bulunmaktadır.

- 16 farklı yerde 25 mahzen.

- Sırt hamamı isimli hamam, Balat'ta 1 hamam, Yenikule dişında Sivudid Manastırı'na bitişik 1 hamam, Galata'da 1 hamam ve Tahtakale hamamı isimli 1 hamam olmak üzere toplam 5 adet hamam.

- 7 farklı yerde 8 bergos.

- Unkapanı ve Yemişkapanı olmak üzere 2 kapan.

- Kale dışında Balat Kapısı yakınında 9 bahçe.

- Terkos Köyü ve tevabii, Eskihisar diye bilinen Loğuz, Eskoz ve Gelenkoz köyleri ile Silivri Kalesi olmak üzere 5 köy.

- 2 adet menzil.

- Fırın yapımı için 1 arazi.

- İstanbul'da zımmilerden alınan cizye vergisinden 200.000 meskük dirhemin vakfa tahsisi.

- Türü belirtilmeyen 4 akar.

Listeden anlaşılacağ 1 üzere Fatih, kurmuş olduğu vakfa oldukça yüksek miktarda gelir getirecek yüksek sayıda akar vakfetmiştir. Bu sayede kurulan vakıf, eserleriyle birlikte günümüzde de ayakta durmaktadır. 


\section{Vakfin Yönetimi \\ 1. Vakfin Yöneticileri \\ a. Mütevelli}

Vakfin mütevellisi, hayatta olduğu müddetçe Fatih Sultan Mehmed'dir. Vakıfta, vakfiyeye uygun olarak dilediği ve istediği şekilde tasarruf edecektir. Vefatından sonra, kendi nesebinden gelen evlatlarından devletin başına geçen evladı mütevelli olacaktır. Bu şarta uyan evladı veya evladının evladı kalmazsa, şer'-i kavîm ve din-i müstakim reyine tefviz olunacaktır (sr. 889-892). Yani şer'-i şerif üzerine muamele olunup hâkim tarafindan mansup mütevelli tayin olunacaktır.

Mütevelli, herşeyden önce bütün davranışlarında Allah'tan korkar olacaktır. Kiracılara diyanet erbabının razı olacağı şekilde davranacak ve kiracılarla sözleşme yapılacağında ihmal etmeyerek şahitler huzurunda sözleşmenin içeriğini ve şartlarını yazacak, sözleşme süresince her hangi bir ihmalde bulunmadan kiraları toplayacak ve helal yatırımlar yapacak, bütün gelirleri toplayacak ve zaptedecektir (sr. 892-896).

Toplanan gelirler, hasılatlar ve kiralar öncelikle vakfa ait yerlerin onarımları ile iki suyolunun yani Kırkçeşme namıyla bilinen çeşmeye bağlı suyoluyla, Yeni Camiye (Fatih Camii) ve Saray'a akan suyollarının tamirine sarf olunacaktır. Eğer vakfın yerlerinden yıkılan olursa, ikinci, üçüncü, dördüncü kez ve sonsuza dek yeniden yapılacaktır. Eğer yeniden yapılmaları mümkün olmazsa vakfın gelirleri Müslüman fakirlere ve miskinlere harcanacaktır. Bu harcamalar yapıldıktan sonra kalan gelir her ne ise, bunun onda biri mütevelliye tevliyet ücreti olarak ödenecektir (sr. 896-899).

Mütevelli, evkafi onarmak, yıkılan ve harap olan yerleri inşa etmek, gedikleri kapatmak ve bunların tekini çift, birini iki yapmak suretiyle tekrar tekrar yapmakla mükelleftir (sr. 956-957).

\section{b. Nazır}

Vakıfta 1 nazır görev yapacaktır (sr. 899). Vakfiyede adı geçen medreseler ve vakfiyede kayıtlı camiler için tayin olunan bu nazıra günlük 40 akçe ücret ödenecektir (sr. 924).

Görüldüğü üzere, vakfiyede yer alan tüm camiler ve medreseler için tek bir nazır görevlendirmiştir. Bu durumda vakfiyede yer alan Fatih, Ayasofya, Galata ve Silivri camileriyle Sahn-1 Seman Medreseleri ve Debbağlar Mahallesi'ndeki mâristanın (darüşşifa) mütevelliden sonraki en üst yöneticisi nazırdır. Nazır vakfin gelir giderlerini de yönetmektedir. 
Fatih'e ait II. Bayezid dönemi 1496 tarihli istinsah vakfiyelerde, Tapu Kadastro Genel Müdürlüğü'nde bulunan vakfiyede ve Vakıflar Genel Müdürlügü̈nde bulunan Türkçe vakfiyede vakfın nazır sayısı 2 olarak belirlenmiştir. Nazırlardan biri Fatih Külliyesi'nin idaresini, diğeri Ayasofya ve diğer hayratın idaresini yürütmektedir. Bu durum, incelemekte olduğumuz bu vakfiyenin, vakfin tekâmülünün tamamlanmasından önceki bir vakfiye olduğunu göstermektedir.

\section{c. Kâtip}

Vakfın kitabet hizmetlerini yürütmek üzere bir de kâtip görevlendirilmiştir. Vakfiyede geçen medreseler ve camilerin hepsinin kitabeti için tayin olunan bu kâtibe günlük 10 dirhem ücret verilecektir (sr. 953). Sonraki tarihli vakfiyelerde, nazırda olduğu gibi Fatih Külliyesi için ayrı, Ayasofya ve diğer müesseseler için ayrı olmak üzere iki kâtip görevlendirilmiştir.

\section{d. Câbi}

Vakfa ait gelirleri toplamak üzere 4 cabi vakıfta görev yapacak, her biri günlük 4'er dirhem ücret alacaktır. Vakfiyede cabiler Ayasofya Camii görevlileri arasında sayılmaktadır (sr. 931-932). Ancak cami göreviyle direk ilgileri olmadığından çalışmamızda cabiler vakfın yönetici kadrosu içerisinde ele alınmıştır. Vakfiyede hangi câbinin hangi akarların gelirlerini toplayacağ belirtilmemiştir. Sonraki tarihlerde düzenlenen vakfiye nüshalarında, câbilerin sayısının 18'e kadar yükseldiği, aralarında iş bölümü yapıldığı ve tahsil bölgelerinin belirlenerek ayrıldığı görülmektedir.

\section{Personel Yönetimiyle İlgili Genel Şartlar}

Vakfın personel yönetimiyle ilgili şartlar vakfiyenin 957-962. satırları arasında belirlenmiş olup aşağıda sıralanmaktadır.

Vakfiyede belirlenen ve tahsis edilen vazifeler (ücretler), vakıftaki artış ve noksan miktarına göre artıp azalabilecektir. Eğer onlardan bir şey fazla olursa, ihtiyaç zamanı için saklanacaktır.

Vakıf görevlileri, geçerli bir engel ve kuvvetli bir özrü bulunmadıkça görevlerini terk etmeyeceklerdir. Bir vazifeye atanan kişi, işinde mukim oldukça ve kendine verilen hizmeti yerine getirdiği müddetçe görevden alınmayacaktır. Şayet doğru yoldan ayrılan olursa mütevelli ona nasihat edecek, görevden almayacaktır. İkinci kez tekerrür ederse nasihatle beraber uyaracak ve tazir edecek ve yine azl etmeyecektir. Yine devam ederse mütevelli o kişiyi görevinden azl edecektir. 


\section{Vakıf Şartlarının Yerine Getirilemez Hale Gelmesi}

Vakfiyede beyan edilen şartlar uygulanamaz hale gelirse, vakıf gelirleri fakir, ihtiyaç sahibi ve miskinlere sarf olunacaktır.

\section{Vakfin Hizmetlerinin Değerlendirmesi}

Medeniyetimizin bir vakıf medeniyeti olduğu, vakıflar üzerinden bir medeniyet inşa edildiği bilinen ve söylenen bir gerçektir. Orta Asya'dan başlayan, bilahare Anadolu ve Balkanlar'a uzanan bu medeniyet inşasında irili ufaklı binlerce vakfın üstlendiği hizmetler, toplamda çok geniş bir coğrafyada medeniyetimizin ortaya çıkması sonucunu doğurmuştur. Vakfiyelerde yer alan hayır müesseseleri ve hayır şartları, hizmetlerin yerine getirilebilmesi için vakfedilen akarlardan elde edilen gelirlerle yüzyıllarca kesintisiz olarak yerine getirilebilmiş ve vakıflar ayakta kalabilmiştir. Doğrudan halka hizmet eden bu kurumlar devletin üzerindeki yükün önemli bir kısmını almıştır. Her vakıf aynı zamanda kurucusunun da içerisinde yer aldığı sosyal çevreyi çok iyi bilme imkânına sahip olduğundan, kurulacak vakıfta verilecek hizmetler, ihtiyaca göre şekillenmiş ve amaca hizmet eder, etkin tesisler olmuşlardır.

\section{Vakfin Hizmet Alanları}

İncelemekte olduğumuz vakfiyeye göre vakfın sosyal politika alanındaki hizmetleri eğitim, dini hizmetler ve sağlık hizmetleri alanında toplanmaktadır. Ayrıca şehre su taşıyan, Kırkçeşme çeşmesine ve saraya su taşıyan suyollarının bakım onarım hizmetlerini de bu vakıf üstlenmiş bulunmaktadır.

\section{a. Ĕ̈itim Hizmetleri}

Vakfiyede yer alan eğitim hizmetleriyle ilgili müessese, Fatih Külliyesi bünyesindeki Sahn-1 Seman Medreseleri'dir. 8 medreseden oluşan bu kurum devrinin en yüksek eğitim veren medreseleridir. 8 medresenin her birinde birer müderris ve muid görev yapmaktadır. Müderrisler ders veren hocaları oluşturmakta, muidler dersten sonra öğrencilere tekrar yaptırmakta ve dersi iyice anlamalarını sağlamaktadırlar. Bu şekilde Sahn-1 Seman Medreseleri'nde 16 kişi eğitmen olarak çalışmaktadır. Sahn-1 Seman Medreseleri'nde ayrıca her biri bir medresede görev yapmak üzere 8 bevvap ve 8 hademe hizmet vermektedir. Bunun dışında 2 hâfız-1 kütüp (kütüphaneci) de medreselerde bulunan kitaplarla ilgili olarak görevlendirilmiş bulunmaktadır. Böylece Sahn-1 Seman Medreseleri'nde görev yapanların sayısı toplam 34 kişiden oluşmaktadır. Vakfiyede medresede eğitim görecek öğrencilerin sayısı hakkında bilgi bulunmamaktadır. Sonraki tarihli vakfiyelerde ise öğrenci sayılarının da belirlendiği görülmektedir. Vakfiyede öğrenci sayısı belir- 
lenmemekle birlikte, öğrencilerin tamamı için günlük 30 dirhem ödenmesi şart edilmektedir.

İncelemekte olduğumuz vakfiyede Fatih Külliyesi'nin bir alt kademe eğitim kurumu olan Tetimme Medreseleri yer almamaktadır. Sonraki vakfiyelerde Tetimme Medreseleri adıyla 8 medresenin daha yer aldığı görülmektedir.

Vakfiyede Ayasofya Camii görevlileri belirlenirken yetimleri okutmak üzere bir de muallim görevlendirilmiş bulunmaktadır. Ancak ayrı bir darüttalimden, sıbyan mektebinden bahsedilmemektedir. Sonraki vakfiyelerde ise Ayasofya'ya bitişik darüttalimde görev yapmak üzere bir muallim görevlendirildiği açıkça ifade edilmektedir.

Fatih, vakfına bağlı olarak devrinin en ileri eğitim kurumu olan Sahn-1 Seman Medreseleri'ni kurarak eğitime verdiği önemi açıkça ortaya koymuştur. Fatih'in kurmuş olduğu diğer bir vakıf olan Eyüp Sultan Vakfi'nın hizmet birimleri arasında da medrese, külliyenin en önemli birimleri arasında yer almıştır. Fatih, sadece medrese kurmakla kalmamış, Fatih Camii ve çevresini bir ilim merkezi haline çevirmek üzere ulema için evler bina etmiş ve âlimleri buralara yerleştirmiştir. Bir müddet sonra Fatih Camii, Sahn-1 Seman Medreseleri ve çevresi İstanbul’un en önemli ilim merkezi haline gelmiştir. ${ }^{28}$

\section{b. Dini Hizmetler}

Vakfiyede dini hizmet müessesesi olarak Fatih, Ayasofya, Galata ve Silivri Kalesi camileri yer almaktadır. Fatih Camii, Fatih Sultan Mehmed'in kendi yaptırdığı camiler arasında yer almaktadır. Ayasofya, Galata ve Silivri Kalesi camileri ise fethin sembolü olarak kiliseden çevrilip vakfa dahil edilen camilerdir. Diğer vakfiyelerde kiliseden çevrilerek vakfedilen müesseseler arasında, Kalenderi dervişlerine zaviye olarak tahsis edilen Kalenderhane ile ilk etapta eğitim hizmetlerinde, Fatih Külliyesi'nin tamamlanmasından sonra ise cami olarak hizmet veren Atik İmaret ve Zeyrek camileri de bulunmaktadır.

Fatih Camii'yle ilgili görevlendirilen personele bakıldığında 1 hatip, 2 imam, 1 baş hâfız, 9 hâfız, 20 hâfız veya ilim ehli kişi, 1 muarrif, 10 müezzin, 6 bevvab,

28 Fatih Sultan Mehmed Han'ın vakfiyelerindeki eğitim şartları, Vakıflar Kanunu'nun verdiği yetkiye istinaden Vakıflar Meclisi kararıyla "her seviyeden eğitim kurumu kurmak" şeklinde değiştirilmiş ve bu değişikliğe binaen 2010 yılında diğer dört kurucu mazbut vakıfla birlikte Fatih Sultan Mehmet Vakıf Üniversitesi kurulmuştur. Vakfın Tevhid-i Tedrisat Kanunu ile durmuş olan eğitim hizmetleri, günümüzde Fatih Sultan Mehmet Vakıf Üniversitesi çatısı altında devam etmektedir. Üniversitenin kuruluş süreci ve hukuki dayanakları, yayımlanma sürecinde olan "Mazbut Vakıfların Günümüz Hayır Hizmetleri” başlıklı makalemizde ele alınmaktadır. 
20 Kelime-i Tevhidhan, 10 Salavathan, 2 kandilci, 1 saatçi ve 2 suyolu tamircisi olmak üzere cami için toplam 85 personel görevlendirildiği anlaşılmaktadır.

Ayasofya Camii'nde 1 hatip, 1 imam, 1 başhâfız, 9 hâfiz, 20 cüzhan, 14 tesbihhan ve tehlilhan, 1 muarrif, 6 müezzin, 2 kandilci, 1 saatçi, 4 kayyım, 2 meremmetçi ve 2 saka olmak üzere 64 kişi görev yapmaktadır. Ayrıca 4 bekçi de, kadroları Ayasofya'da olmak üzere Kapalı Çarşı' da görev yapmaktadır.

Galata Camii'nde 1 hatip, 1 imam, 3 hâfız, 2 müezzin, 2 kayyım, 1 kandilci ve 1 muarrif olmak üzere toplam 11 kişi, Silivri Camii'nde ise hatip, imam, müezzin, muarrif ve kayyım olarak 1'er kişi olmak üzere 5 kişi görev yapmaktadır.

Böylece vakfın dört dini hizmet müessesesinde görev yapan kişi sayısı toplam 163 'ü bulmaktadır. Kadrosu Ayasofya'da olduğu için Kapalı Çarşı'da görevli 4 bekçi de eklendiğinde bu sayı 167'yi bulmaktadır. Oldukça yüksek sayıda görevlinin bu camilerde vazife yapıyor olması, Fatih'in İstanbul'u bir İslam şehrine çevirme konusundaki niyetini, kararlığını, ciddiyetini ortaya koymakta, işi sıkı tuttuğunu göstermektedir.

\section{c. Săglık Hizmetleri}

İncelemekte olduğumuz vakfiyede vakfin sağlık tesisi Debbağlar Mahallesi'nde bulunan ve eskiden bimarhâne adıyla anılan mâristan - darüşşifadır. Bu tesis sadece bu vakfiyede yer almakta, sonraki vakfiyelerde bulunmamaktadır. Sonraki vakfiyelerde vakfin sağlık tesisi Fatih Külliyesi bünyesindeki darüşşifadır. Anlaşıldığı kadarıyla, Fatih Külliyesi'ndeki darüşşifa hizmete girene kadar Debbağlar Mahallesi'ndeki darüşşifada vakıf sağlık hizmeti verilmiş, Fatih Külliyesi'nin tamamlanmasıyla birlikte bu hizmet külliyeye taşınmıştır. Debbağlar Mahallesi'ndeki darüşşifa ise kapanmış ve günümüze gelmemiştir.

Vakfiyede darüşşifadan yararlanacak olanlar hastalar, maluller, kötürümler ve ilaca ve beden sağlığına muhtaç olanlar şeklinde belirlenmiştir (sr. 33-36). Görüldüğü üzere halk dil, din, ırk ayrımı yapılmaksızın sağlık hizmetlerinden yararlanabilmektedir.

Darüşşifada, 1 nazır, 1 tabip, 1 cerrah ve 2 hademe (hasta bakıc1) olmak üzere 5 sağlık görevlisi bulunmaktadır. Darüşşifaya bağlı bir de tabhane (aşhane) bulunmaktadır ve burada hastalar için yemek çıkarılmaktadır. Tabhanede 2 aşçı, 1 kilerdar, 1 vekilharç, 1 kâtip olmak üzere 5 kişi görev yapmaktadır. Böylece darüşşifanın tabhaneyle birlikte toplam personel sayısı 10'u bulmaktadır.

10 dirhemi sergi, yorgan, yatak, elbise ve bürünülecek şeylere, geri kalanı sair alet, edevat, ilaç ve eczaya harcanmak üzere darüşşifa harcamaları için vakıftan günlük 100 dirhem tahsis edilmiştir. Darüşşifada bulunan ecza, ilaç, gıda 
ve tedavide kullanılan eşyalar, doktorun uygun gördüğü şekilde sarf olunacak, hastane dışına verilmeyecektir. Ancak bunların dışarıda bulunmaması veya elde edilmesinin güç olduğu durumlarda dişarıyada verilebilecektir.

\section{d. Suyollarının Bakım Onarım Hizmetleri}

Vakfın yürüttüğü diğer bir hizmet, Kırkçeşme isimli çeşmenin, Fatih Camii'nin ve günümüzde Beyazıt'ta İstanbul Üniversitesi'nin bulunduğu eski sarayın suyollarının tamir, bakımının yapılması, hatta gerekirse bu suyollarının yeniden yapılmasıdır. Bahsi geçen suyolları, aynı zamanda şehre de su taşıyan suyollarıdır. Vakıf olarak bu hizmet üstlenilerek bir yönüyle şehrin su ihtiyacının karşılanması konusunda önemli bir hizmet yerine getirilmiştir. Vakıfta 2'si Fatih Camii kadrosunda, 2'si Ayasofya Camii kadrosunda olmak üzere toplam 4 suyolu tamircisi istihdam edilmektedir.

\section{Vakıf Hizmetlerinin Finansmanı}

Vakıf hizmetlerinin ilelebet sürdürülebilmesi için vakıf gelirlerinin giderleri karşılar nitelikte olması gereklidir. Bu da vakfın akar niteliğindeki mallarının yeterli seviyede olmasıyla sağlanabilir. Fatih'in kurmuş olduğu Fatih Külliyesi ve Ayasofya-i Kebir Vakfı oldukça büyük bir vakıftır. Bu vakfın hizmetlerinin sürekliliği de külliyetli gelir gerektirmekte olduğundan vakfın akar türündeki malları bir hayli fazladır.

Vakfın akarları bölümünde akar türleri ve sayıları verilmiştir. Vakfiyenin 41-174. satırlarında (5-100 arası akarlar), özellikle Kapalı Çarşı ve etrafındaki çarşılar, hanlar, sur içerisindeki kapanlar, pazarlar ve bir çok dükkânın bir arada bulunduğu akarlar ile Unkapanı ve Balat'ta bulunan büyük çaplı akarlar yer almaktadır. Bu kapsamda, Kapalı Çarşı (Bezzazistan / Bedesten), Kapalı Çarşı civarlarında bulunan İplik Bükücüler, Bit Pazarı, Külahçılar Çarşısı, Kavaflar Çarşısı, Saraçlar Çarşısı, Hallaçlar Çarşısı, Bedesten etrafındaki dükkânlar, Yeni Bedesten, Sultan Hanı (Yeni Han), Tavukçular Çarşısı, Debbağlar (Dericiler) Çarşısı, Eski Bozahaneler, Bakırcılar Çarşısı, Eski Kervansaray, İplikçiler Çarşısı, Karamanlılar Çarşısı (Karaman Pazarı), Unkapanı, Yağhane, Salhane, Yemişkapanı, Balıkçılar Çarşısı, Balat Pazarı gibi şehrin en büyük ve en önemli çarşı - pazarları ve dükkânları vakfiyenin bu kısmında Fatih Sultan Mehmed Han Vakfi'na ait akar olarak kayıtlı bulunmaktadır. Ayrıca yine binlerle ifade edilen dükkân, ev, hücre, oda türünde akar vakfiyede yer almaktadır. Ayrıca, cizye gelirlerinden yıllık 200.000 akçe vakfa tahsis edilmiştir.

Tüm bunlar birlikte değerlendirildiğinde Fatih'in, kurduğu vakıfta yürütülecek hizmetleri, müesseselerin bakım, onarım ve yeniden inşasını, personel gider- 
lerini karşılayacak miktarın çok daha fazlası büyüklüğünde bir mal varlığını akar olarak vakfettiği anlaşılmaktadır.

\section{Sonuç}

Fatih'in İstanbul'u fethiyle birlikte şehrin yeniden imar ve iskânında önemli rol alan vakıflar arasında Fatih'in kurduğu "Fatih Külliyesi ve Ayasofya-i Kebir Vakfı" da yer almaktadır. Bu vakfa ait muhtelif vakfiye nüshaları arasından Türk ve İslam Eserleri Müzesi'nde 2202 numara ile kayitlı vakfiye üzerinden yaptığımız çalışmada vakfın hayır müesseseleri, hayır şartları, akarları, yönetimi ele alınmıştır. Vakıf sosyal politika alanında önemli hizmetler üstlenmiştir. $\mathrm{Bu}$ bağlamda vakfın eğitim hizmetleri, dini hizmetler ve sağlık hizmetleriyle ön plana çıktığı görülmektedir. Vakfın ve hizmetlerinin devamlılığını sağlamak üzere oldukça fazla sayıda çarşı, pazar, dükkân, ev akar olarak vakfedilmiştir.

Üzerinde çalış1lan vakfiyede, vakfa ait diğer vakfiye nüshalarında yer alan bazı birimlerin bulunmadığı görülmektedir. Yine diğer vakfiye nüshalarında yer almayan Debbağlar Mahallesi'ndeki darüşşifa sadece bu vakfiyede yer almaktadır. Vakfiye nüshaları arasındaki bu farklılıkların anlaşılabilmesi için vakfiye olarak kabul edilen tüm nüshaların çevirilerinin yapılarak karşılaştırılması gerektiği kanaatine varılmıştır. Yayımlanmış diğer vakfiye nüshaları incelendiğinde, Fatih devrine tarihlenen nüshalarda vakfin bazı birimlerinin vakfiyelerde yer almad1$\breve{g} 1$, II. Bayezid döneminde istinsah edilen nüshalarda ise artık vakfin tekâmül ettiği ve tüm birimlerinin bu vakfiye nüshalarında yer aldığı görülmektedir. $\mathrm{Bu}$ da vakfın Fatih döneminde başlayan kuruluş ve gelişme sürecinin II. Bayezid döneminde tamamlandığı sonucunu doğurmaktadır. 


\section{Kaynakça}

\section{Arşiv}

Fatih Külliyesi ve Ayasofya-i Kebir Vakfiyesi (1472/1473), Türk ve İslam Eserleri Müzesi, Defter no. 2202 (eski 666) (asıl nüsha); Vakıflar Genel Müdürlügü Arşivi, Defter Nr. İstanbul 6. Vakfiye Defteri, Sıra Nr. 46 (Evkaf Nezareti kayd1); Vakıflar Genel Müdürlüğü Arşivi, Defter Nr. 575, sayfa 82 vd, Sıra Nr. 46 (Arapça'dan Türkçe'ye Latin harfli çeviri kaydı).

\section{Kitap, Makale ve Tezler}

Akgündüz, Ahmet - Öztürk, Sait - Baş, Yaşar, Üç Devirde Bir Mabed: Ayasofya, İstanbul, OSAV Yayınları, 2005.

Aktaş, Seyran, "XV. ve XVI. Yüzyıllarda Sutan Dârüşşifâları", (Yayımlanmamış Yüksek Lisans Tezi), Gazi Üniversitesi S.B.E., Ankara, 2010.

Ayverdi, Ekrem Hakk1, Fatih Devri Sonlarında İstanbul Mahalleleri, Şehrin İskânı ve Nüfusu, Ankara, Vakıflar Umum Müdürlüğü Yayınları, 1958.

Barkan, Ömer Lütfi - Ayverdi, Ekrem Hakkı, İstanbul Vakıfları Tahrir Defteri 953 (1546) Tarihli, İstanbul, İstanbul Fetih Cemiyeti İstanbul Enstitüsü Yayınları, 1970.

Beyatl, Ahmet, Fâtih Sultan Mehmed'in 877/1472 Tarihli Vakfiyyesi, Ankara, Türk Tarih Kurumu Yayınları, 2013.

Canatar, Mehmet, İstanbul Vakıflarl Tahrir Defteri 1009-(1600), İstanbul, İstanbul Fetih Cemiyeti Yayınları, 2004.

Ergin, Osman, Fatih İmareti Vakfyesi, İstanbul, İstanbul Belediyesi Yayınları, 1945.

Erkal, Namık, “İstanbul'da Erken Dönem Osmanlı Mimarisi”, Antik Çağdan XXI. Yüzylla Büyük İstanbul Tarihi - Mimari, c. VIII, İstanbul, İstanbul Kültür A.Ş. Yayınları, 2015.

Kafescioğlu, Çiğdem, Constantinapolis / İstanbul, Pennslyvania, The Pennsylvania State University Press, 2009.

Öz, Tahsin, Zwei Suftuftungsurkunden des Sultans Mehmed II. Fatih, İstanbul, Alman Arkeoloji Enstitüsü Yayınları, 1935.

Sönmez, Zeki, "Sinân-1 Atik", Türkiye Diyanet Vakfi İslam Ansiklopedisi (DIA), c. 37, 2009.

Şehsuvaroğlu, Bedi N., Türk Tip Tarihi, Bursa, 1984. 
Unan, Fahri, Kuruluşundan Günümüze Fâtih Külliyesi, Ankara, Türk Tarih Kurumu Yayınları, 2013.

Ünver, A.Süheyl, Fatih Külliyesi ve Zamanı İlim Hayatı, İstanbul, İstanbul Üniversitesi Yayınları, 1946.

Vakıflar Genel Müdürlüğü, Fatih Mehmet II Vakfiyeleri, Ankara, Vakıflar Genel Müdürlüğü Yayınları, 1938.

Vakıflar Genel Müdürlüğü - Çamlıca Kültür ve Yardım Vakfı, Fatih Sultan Mehmed Vakfiyeleri, İstanbul, VGM ve Çamlıca Kültür ve Yardım Vakfı Yayınları, 2003. 